\title{
The subchronic toxic effects of plant growth promoters in mice ${ }^{*}$
}

\author{
Selma YAZAR $^{1}$, Emine BAYDAN ${ }^{1}$ \\ ${ }^{1}$ Department of Pharmacology and Toxicology, Faculty of Veterinary Medicine, Ankara University, Ankara, Turkey.
}

\begin{abstract}
Summary: The aim of this study was conducted to subchronic toxic effects separate and combined using of maleic hydrazide and ethephon in female mice. Treatment group divided into 9 groups according to chemicals' doses and compared with controls. Three separate maleic hydrazide doses (100-200-400 mg/kg/day, in feed) and ethephon (50-100-150 mg/kg/day, in water) were given alone and in combination during 45 days. At the end of the study, aspartate aminotransferase, alanine aminotransferase, urea and creatinine levels in blood samples were evaluated. Liver and kidney tissues were taken and examined histopathologically. As a result, alone usages of maleic hydrazide caused liver, kidney toxicity. Toxic effects were clearer in liver; however with ethephon, toxicity was more moderate than maleic hydrazide. In combination, glomerulonephritis were seen in the highest doses. As a result, plant growth promoters could be harmful on kidney and liver. Producers and consumers should become more conscious about the toxic effects of these chemicals.
\end{abstract}

Key words: Ethephon, kidney, liver, maleic hydrazide, mice, toxicity.

\section{Bitki büyüme hormonlarının farelerdeki subkronik toksik etkileri}

Özet: Bu çalışma, maleik hidrazid ve etefonun tek ve kombine kullanımının dişi farelerdeki subkronik toksik etkilerini değerlendirmek amacıyla yapıldı. Çalışma grupları kimyasal maddelerin dozlarına göre 9 gruba ayrıldı ve bunlar kontrol grubuyla karşılaştırıldı. Maleik hidrazid (100-200-400 mg/kg/gün, yemle) ve etefon (50-100-150 mg/kg/gün, su ile)'nun 3 farklı dozu tek ve kombinasyon şeklinde 45 gün süresince verildi. Çalışmanın sonunda, kan örneklerindeki aspartat aminotransferaz, alanin aminotransferaz, üre ve kreatinin düzeyleri değerlendirildi. Karaciğer, böbrek dokuları alınarak histopatolojik inceleme yapıldı. Maleik hidrazidin tek başına kullanımında karaciğer ve böbrekde toksisiteye sebep olduğu belirlendi. Bu toksisite özellikle karaciğerde daha belirgin olmakla birlikte, etefonun toksistesitesi maleik hidrazidden daha 1lımlıydı. Kombinasyonlarda ise, yüksek dozlarda glomerulonefritis görüldü. Sonuç olarak, bitki büyüme hormonları karaciğer ve böbrek üzerinde zararlı etkileri olabilmektedir. Üretici ve tüketicilerin bu kimyasalların toksik etkileri konusunda daha çok bilinçlendirilmesi gerekmektedir.

Anahtar sözcükler: Böbrek, etefon, fare, karaciğer, maleik hidrazid, toksisite.

\section{Introduction}

A lot of chemicals substances including plant growth promoters are used in agriculture (9). Maleic hidrazide and ethephon are two chemicals in this group which are licensed as chemicals and are commonly used in Turkey.

Maleic hidrazide is a major commercial herbicide and it is a regulator of the growth of buds in vegetables during storage $(8,13)$. Ethephon-[(2-chloroethyl) phosphonic acid]-which is from the class of organophosphorus is known as ethylene generator and plant growth regulator (11).

Plant growth promoters could not be harmful for human health if applied in adequate doses and convenient time on plants. However, the knowledge regarding the combined toxicity effects of PGRs on the mammals is limited. Therefore, in this study we wanted to evaluate subchronic toxic effects of these two chemicals while using separate and in combination.

\section{Materials and Methods}

Chemical material: Maleic hidrazide (18\% purity; maleic hydrazide potassium salt) and ethephon (48\% purity; ethephon) were used in this study. Maleic hidrazide obtained from a chemical company-Hektas, Ankara, Turkey and ethephon obtained from a chemical company- Aventis, Istanbul, Turkey.

Animals and housing: One hundred 6-month-old, approximately $35-40 \mathrm{~g}$ weighted Swiss albino healthy mice were used in this study. The Ethic Committee of the Faculty of Veterinary Medicine, University of Ankara, Turkey, approved this study. These mice were obtained from Ministry of Health Refik Saydam Hifzisihha Head Center-Ankara, Turkey.

\footnotetext{
* Bu çalışma "Farelerde Maleik hidrazid ve Etefonun tek ve kombine haldeki subkronik toksik etkilerinin araştırılması" isimli doktora tez çalışmasından ingilizce olarak özetlenmiş bir bölümüdür.
} 
Bioassay: Treatment group was divided into 9 groups according to using chemicals' doses. Treatment group was compared with 10 healthy female mice as the control group. Maleic hidrazide was given 100-200$400 \mathrm{mg} / \mathrm{kg} /$ day, per-os, in feed. Also, each group of these chemical doses was included 10 female mice (for maleic hydrazide, 30 mice); ethephon was given 50-100$150 \mathrm{mg} / \mathrm{kg} /$ day, per-os, in water. There were 10 female mice in each dose groups (for ethephon, 30 mice). Besides, $50 \mathrm{mg} / \mathrm{kg} /$ day dose of ethephon was combined with $100 \mathrm{mg} / \mathrm{kg} /$ day maleic hidrazide, $100 \mathrm{mg} / \mathrm{kg} /$ day ethephon was combined with $200 \mathrm{mg} / \mathrm{kg} /$ day maleic hidrazide and $150 \mathrm{mg} / \mathrm{kg} /$ day ethephon was combined with $400 \mathrm{mg} / \mathrm{kg} /$ day maleic hidrazide. Each group of this combination was included 10 mice, totally 30 mice. The study lasted 45 days. All the animals were fed ad libitum pelleted diet.

Liquid maleic hidrazide was mixed with ground pellet. After this process, the mixture was returned to the form of pellet, put in incubator for drying at a temperature of $100-150{ }^{0} \mathrm{C}$ for a period of $1-1.5$ hours. After this process, all the mice in maleic hidrazide group were fed with this prepared pellet. Besides, they were given water during the study. Because of the stability of liquid, ethephon could be spoiled above $75{ }^{0} \mathrm{C}$. Therefore, this chemical was given in water with no pioneer operation (15). Additional water was not available. The lethal doses of these chemicals $\left(\mathrm{LD}_{50}\right)$ were found in the previous literature $(2,5)$. The given doses of the chemicals were calculated according to the information in the studies mentioned above.

Blood was taken from the treatment and control groups directly from the heart put into the tubes by a thin tip injector without using anaesthetic substances. All collected blood samples were centrifuged at $3000 \mathrm{rpm}$ for 10 minutes within 1 hour after sampling and stored at $18{ }^{0} \mathrm{C}$ until analysis. Levels of the following were examined in the aspartat aminotransferase (AST), alanine aminotransferase (ALT), urea and creatinine in an autoanalyzer (Olympus AU 60). The results of the control group were compared with the $45^{\text {th }}$ days of all of the treatment groups. These results were summarized in a Table 1 . On the $45^{\text {th }}$ day of the study, all the mice were sacrificed with diethyl ether. Liver and kidney tissues were taken and examined histopathologically. Liver and kidney of the mice were prepared within 1 hour after sacrification of the mice and fixed in $10 \%$ formal saline solution. After routine processing, paraffin sections of each tissue were cut at $6 \mu \mathrm{m}$ thicknesses and stained with haematoxyline-eosin for microscopic.

Statistical analysis: The statistical package SPSS for windows (release 11.0) were used for data analysis. Numerical values were reported as mean \pm SD of the sample size. A p value $\leq 0.05$ was accepted as statistically significant.

\section{Results}

According to the results of statistical analysis of the control group and on the $45^{\text {th }}$ day of the treatment group which was exposed to maleic hydrazide alone, in mice, urea, creatinine and AST values were found higher than controls in all of the doses of maleic hydrazide but ALT was found higher with maleic hydrazide $400 \mathrm{mg} / \mathrm{kg} /$ day. Statistical evaluation of the control group and on the $45^{\text {th }}$ day of the treatment group using ethephon alone was done. Urea and AST values were found higher than controls in all doses of ethephon. ALT values were higher with ethephon, $50-150 \mathrm{mg} / \mathrm{kg} / \mathrm{day}$ but creatinine values were found higher only with ethephon $150 \mathrm{mg} / \mathrm{kg} /$ day.

When the results of the control group was compared with the treatment group results on the $45^{\text {th }}$ day, creatinine and AST values were found higher than control females doses in all combination of maleic hydrazide and ethephon but urea values were found higher in the two last combined doses group (maleic hydrazide, 200+ethephon, $100 \mathrm{mg} / \mathrm{kg} /$ day; maleic hydrazide, $400+$ ethephon, $150 \mathrm{mg} / \mathrm{kg} /$ day). However, no other significant statistical difference was found in the above mentioned groups (Table1).

Macroscopic findings of the livers, in the alone maleic hydrazide treated group, more prominent pin point sized whitish grey foci on the parietal side of the liver and more yellowish discoloration in the tissue were observed in mice when compared with the controls. These were more significant at the second and the third doses of maleic hydrazide. Microscopic findings of the livers, when compared with the controls, microscopic evaluation of the livers of the mice, acute swelling of the cells, coagulation necrosis and erythrocytes included hepatocytes were seen. No macroscopic liver changes were seen in alone treated group with ethephon. Microscopic liver changes, hyperaemic areas were observed in mice in the alone ethephon treated group.

Macroscopic findings of the kidneys, no macroscopic changes were seen in all the treatment groups when compared with the controls. Microscopic findings of the kidneys, treated group with maleic hydrazide, when compared with the controls, degenerative change and hyperaemia were seen in tubules. In the combine treated groups, in macroscopic examination, liver colour changes were clearer than the separate usages of each of the chemicals. Microscopic examination, in the last combination group (maleic hydrazide, 400+ ethephon, $150 \mathrm{mg} / \mathrm{kg} /$ day), severe passive hyperaemia, patchy mononuclear cell infiltration around the venules and degenerative hepatocytes changes around the bleeding areas were seen. Also, changes to chronic cirrhosis were observed in mice. In mice, bleeding 
Table 1. Comparation of control and $45^{\text {th }}$ days of biochemical values of mice.

Tablo 1. Farelerin kontrol ve 45. gün biyokimyasal değerlerinin karşılaştırılması.

\begin{tabular}{|c|c|c|c|c|c|c|c|c|}
\hline $\begin{array}{l}\text { Doses (mg/kg/day) } \\
\text { (Cont and 45.days) }\end{array}$ & $\begin{array}{c}\text { Urea } \\
(\text { Mean } \pm \text { SD })\end{array}$ & $\mathrm{p}$ & $\begin{array}{l}\text { Creatinine } \\
(\text { Mean } \pm \text { SD) }\end{array}$ & $\mathrm{P}$ & $\begin{array}{c}\text { AST } \\
(\mathrm{Mean} \pm \mathrm{SD})\end{array}$ & $\mathrm{P}$ & $\begin{array}{c}\text { ALT } \\
(\mathrm{Mean} \pm \mathrm{SD})\end{array}$ & $\mathrm{P}$ \\
\hline MH 100 (Cont) & $71 \pm 8$ & & $0,4 \pm 0,2$ & & $155 \pm 20$ & & $52 \pm 15$ & \\
\hline MH 100 (45) & $86 \pm 11$ & 0.00 & $1.6 \pm 0.2$ & 0.00 & $212 \pm 65$ & 0.02 & $62 \pm 16$ & 0.25 \\
\hline MH 200 (Cont) & $71 \pm 8$ & & $0,4 \pm 0,2$ & & $155 \pm 20$ & & $52 \pm 15$ & \\
\hline MH200 (45) & $86 \pm 14$ & 0.04 & $1.2 \pm 0.1$ & 0.00 & $210 \pm 55$ & 0.01 & $64 \pm 18$ & 0.15 \\
\hline MH 400 (Cont) & $71 \pm 8$ & & $0,4 \pm 0,2$ & & $155 \pm 20$ & & $52 \pm 15$ & \\
\hline MH 400 (45) & $85 \pm 6$ & 0.00 & $1.4 \pm 0.3$ & 0.00 & $335 \pm 4$ & 0.00 & $35 \pm 6$ & 0.03 \\
\hline E 50 (Cont) & $71 \pm 8$ & & $0,4 \pm 0,2$ & & $155 \pm 20$ & & $52 \pm 15$ & \\
\hline E $50(45)$ & $84 \pm 10$ & 0.02 & $0.4 \pm 0.1$ & 0.11 & $216 \pm 51$ & 0.00 & $71 \pm 12$ & 0.00 \\
\hline E 100 (Cont) & $71 \pm 8$ & & $0,4 \pm 0,2$ & & $155 \pm 20$ & & $52 \pm 15$ & \\
\hline E $100(45)$ & $86 \pm 10$ & 0.00 & $0.4 \pm 0.2$ & 0.08 & $246 \pm 66$ & 0.00 & $54 \pm 12$ & 0.71 \\
\hline E 150 (Cont) & $71 \pm 8$ & & $0,4 \pm 0,2$ & & $155 \pm 20$ & & $52 \pm 15$ & \\
\hline E $150(45)$ & $96 \pm 18$ & 0.00 & $0.5 \pm 0.2$ & 0.00 & $231 \pm 5$ & 0.00 & $75 \pm 14$ & 0.00 \\
\hline MH100+E50 (Cont) & $71 \pm 8$ & & $0,4 \pm 0,2$ & & $155 \pm 20$ & & $52 \pm 15$ & \\
\hline MH100+E50 (45) & $81 \pm 14$ & 0.11 & $1.2 \pm 0.3$ & 0.00 & $188 \pm 24$ & 0.02 & $58 \pm 15$ & 0.36 \\
\hline MH200+E100 (Cont) & $71 \pm 8$ & & $0,4 \pm 0,2$ & & $155 \pm 20$ & & $52 \pm 15$ & \\
\hline MH200+E100 (45) & $56 \pm 10$ & 0.00 & $1.2 \pm 0.2$ & 0.00 & $181 \pm 13$ & 0.02 & $51 \pm 13$ & 0.92 \\
\hline MH400+E150 (Cont) & $71 \pm 8$ & & $0,4 \pm 0,2$ & & $155 \pm 20$ & & $52 \pm 15$ & \\
\hline MH400+E150 (45) & $86 \pm 11$ & 0.00 & $2.1 \pm 0.2$ & 0.00 & $324 \pm 19$ & 0.00 & $69 \pm 20$ & 0.10 \\
\hline
\end{tabular}
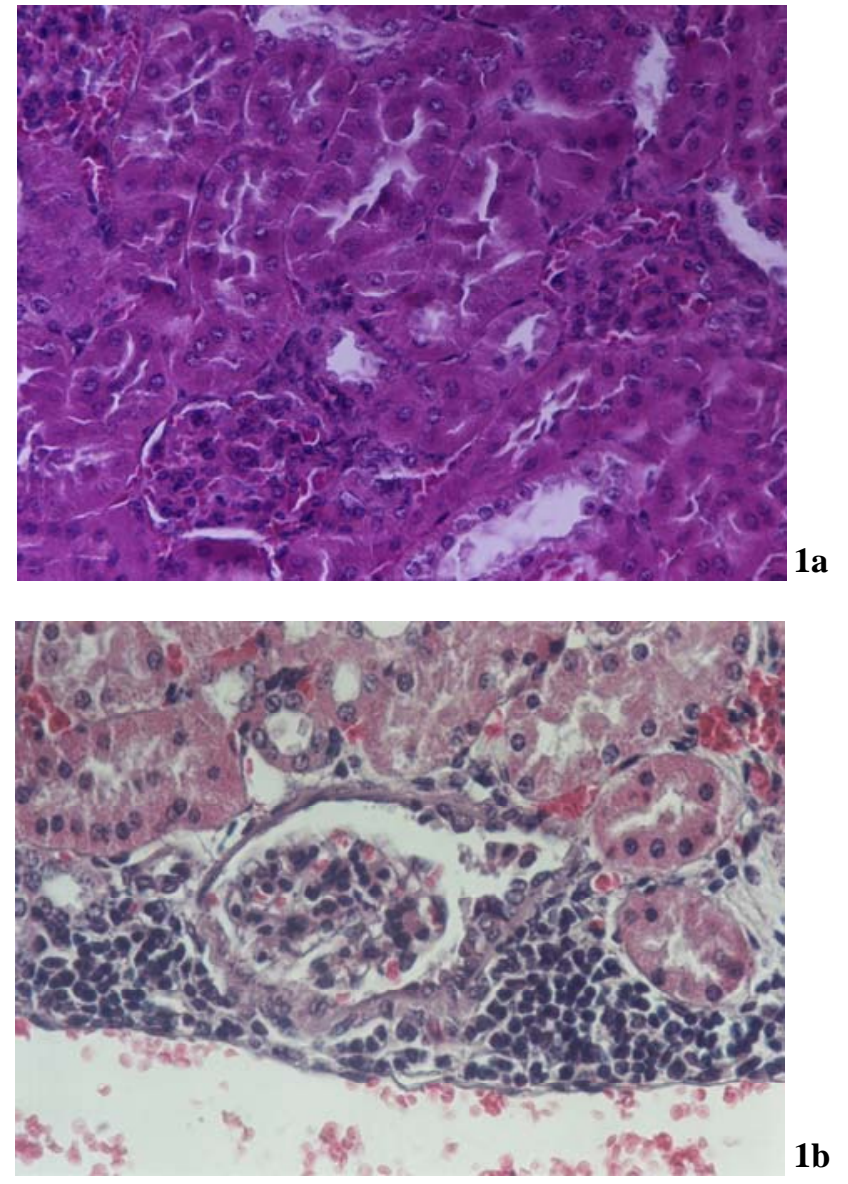

Figure 1a. Control group kidney microscopic appearance, $1 \mathrm{~b}$. Combination group (MH400+E150 $\mathrm{mg} / \mathrm{kg} / \mathrm{day})$ kidney microscopic appearance (HXEX10).

Şekil 1a. Kontrol grubunun böbrek mikroskobik görünümü 1.b. Kombinasyon grubunun (MH400+E150 mg/kg/gün) böbrek mikroskobik görünümü (HXEX10). to the intertubular region, degenerative changes in the tubular epithelial cells, hyaline cells in the tubules and glomerulonephritis were observed (Figure 1a and 1b).

\section{Discussion and Conclusion}

Related studies are very limited about the toxicological or biological results of these chemicals on higher animals (18). Mixture using of pesticides or insecticides to control the menace of pest for better agricultural yield is a common phenomenon (1). Also, in Turkey these resembling combinations are widely used. However, the knowledge about toxic effects of combined using of plant growth promoters on the mammals is not sufficient.

According to the literature, there is no other study about subchronic toxic effects of combined using of maleic hydrazide and ethephon on the liver and kidney of mice. Therefore, this is the first study on this subject. Numerous experiments conducted with various plant species showed that maleic hydrazide acts as an inhibitor of the synthesis of nucleic acids and proteins. However, reported carcinogenic effects of maleic hydrazide in mice and rats raised the question of its risks to man, so conducting studies have become intense regarding this subject $(10,13,14)$.

We have not accessed to adequate knowledge about the subchronic liver or kidney toxic effects of maleic hydrazide. The only related study was about the chronic toxic effects of maleic hydrazide on mice kidney and liver, conducted by (6). The author examined the longterm toxicity of potassium maleic hydrazide on mice 
during 23 months. Clinical signs, body-weight gain, and food consumption were found unaffected by administration of chemical. Also, blood samples showed no effects of treatment but amyloidosis was seen high in various organs including kidney and liver in a doserelated manner in males in all treated groups but in females only at the highest dose. However, we found decreased body-weight gain as a subchronic toxic effect of this chemical. Also, maleic hydrazide caused elevation of kidney and liver enzymes in females. Amiloidosis was not seen in the histopathology examination of our samples but findings were concordant with chronic kidney and liver diseases. Toxic effects on liver and kidney were in a dose-related manner in mice.

Van Der Heijden et al. (17), examined the carcinogenetic effects of maleic hydrazide on rats during 28 months at dietary levels of $0,1.0$ and $2.0 \%$ maleic hydrazide and found proteinuria and increased protein/creatinine ratio's in the urine in both sexes without detectable histopathological changes in kidney or urinary tract as the side effects of the chemical. Although we didn't examine urine but findings of histopathology of kidney showed diversity with the chronic kidney disease findings.

The authors examined the long-term toxicity of potassium maleic hydrazide on Sprague-Dawley rats. Females at $500 \mathrm{mg} / \mathrm{kg}$ bw per day had increased ALT but similar changes were not recorded subsequently. Nondose related change in the pattern of renal lesions was seen in females. The incidences of hydronephrosis and proteinaceous plugs in the urinary bladder were found increased in males at the highest dose (6). Similar changes of increased ALT levels were seen in our study. Moreover, dose related renal changes were seen in females.

The authors studied on beagle dogs. These dogs received a diet containing potassium maleic hydrazide. The findings at necropsy of one male included enlarged liver and kidneys. Body-weight gain was found decreased in dogs. Increased serum enzyme activities and decreased albumin levels consistent with pathological effects in the liver were seen. Also, high frequencies of inflammatory lesions were seen in animals at the highest dose (6). In the results of our study enlargement of liver and kidney was not found but as similarly of the mentioned study, either decreased body weight gain of each sex or increased serum enzymes activities were found. Pathological effects were seen in both liver and kidney. Increased frequencies of inflammatory lesions were seen in kidney at the highest dose.

Ethephon has two seemingly unrelated types of biological activity. E has been shown to inhibit cholinesterase and particularly plasma butyrylcholines- terase, in rats, mice, dogs and humans in vivo. Most of the findings of the studies in literature were on this mechanism of chemical $(3,4,19)$. Moreover, related studies with ethephon were very limited. We found no study about subchronic liver and kidney toxic effects of ethephon on mice. However, there are three studies on humans that examined the subchronic toxicity of ethephon on humans. All of these studies were about the plasma cholinesterase activity of this chemical. No gross symptoms or changes in haematological, clinical, chemical or urine end-points in the examinations (7). The single related study on liver belonged to (12). The authors studied adult Wistar rats during 7 days. They received diets containing of the phosphonic acid derivatives. The effects of ethephon and trichlorphon on cholesterol and other lipids were investigated. The important findings of this study were significantly increasing of liver lipids with ethephon. Although we didn't examine serum lipid values, steatosis was found in mice.

In conclusion, although kidney shown as a target organ for by (16), alone usages of maleic hydrazide caused chronic liver and kidney toxicity in our study. Toxic effects on females' liver were more evident. However with ethephon, toxicity was more moderate than maleic hydrazide. In combination, supporting synergistic toxic effects of these two chemicals glomerulonephritis in females were seen especially in the highest combination doses. The results of this study showed that plant growth promoters could be harmful on kidney and liver even if applied in adequate doses. It should be noted that it is impossible to forbid the utilization of these kinds of chemicals but producers and consumers should be in conscious on the probable toxic effects of these chemicals, which could be important for public health.

\section{Acknowledgments}

This research was apart of a $\mathrm{PhD}$ thesis. I'm grateful to Assistant Professor Latife Beyaz for histopathological study of this thesis. Also special thanks to Assistant Professor Ayse Tunca for her assistance, patience, sound advice, guidance, instructions, for revising the language of this manuscript.

\section{References}

1. Durham WF (1967): The interaction of pesticides with other factors. Residue Rev, 18, 21-103.

2. Food and Agriculture Organization (FAO) (2001): FAO specifications and evaluations for agricultural pesticides. Maleic hydrazide. Erişim:[http://www.fao.org/ag/AGP/ AGPP/Pesticid/Specs/docs/Pdf/new/d+e/e maleic.pdf].

Erişim tarihi:31.01.2001. 
3. Haux JE, Quistad GB, Casida JE (2000): Phosphobutyrylcholinesterase: phosphorylation of the esteratic site of butyrylcholinesterase by ethephon [(2chloroethyl)phosphonicacid]dianion. Chem Res Toxicol, 13, 646-651.

4. Haux JE, Lockridge O, Casida JE (2002): Specificity of ethephon as a butyrylcholinesterase inhibitor and phosphorylating agent. Chem Res Toxicol, 15, 1527-1533.

5. International Programme on Chemical Safety (Inchem) (1993):Pesticide residues in food: 1993 evaluations Part II Toxicology. Ethephon.

Erişim:[http://www.inchem.org/documents/jmpr/jmpmono/ v93 pr07.htm]. Erişim tarihi: 23.01.2005.

6. International Programme on Chemical Safety (Inchem) (1996): Pesticide residues in food: 1996 evaluations PART II Toxicology. Maleic Hydrazide.

Erişim:[http://www.inchem.org/documents/jmpr/jmpmono/ v96pr08.htm].Erişim Tarihi: 20.07.2004.

7. International Programme on Chemical Safety (Inchem) (2002): Pesticide Residues in food-2002- Joint FAO/WHO meeting on Pesticide Residues. Ethephon.

Erişim:[http://www.inchem.org/documents/jmpr/jmpmono/ 2002pr05.htm].Erişim tarihi: 25.07.2004.

8. Marcano L, Carruyo I, Del Campo A, Montiel $\mathbf{X}$ (2004): Cytotoxicity and mode of action of maleic hydrazide in root tips of Allium cepa L. Environ Res, 94, 221-226.

9. Mickel LG (1978): Plant growth regulators: controlling biological behaviour with chemicals. Chem Eng News, 56,18.

10. Ponnampalam R, Mondy NI, Babish JG (1983): $A$ review of environmental and health risks of maleic hydrazide. Regul Toxicol Pharm, 3, 38-47.

11. Segall Y, Grendell RL, Toia RF, Casida JE (1991): Composition of technical ethephon (2-chloroethylphosphonic acid) and some analogs relative to their reactivity and biological activity. J Agric Food Chem, 39, 380-385.
12. Seidler H, Ackermann H, Harting M, Koslowski C (1979): Effect of the phosphonic acid derivatives ethephon and trichlorphon the incorporation in vivo of (14C) acetate into cholesterol and other lipids in rats. Acta Biol Med Ger, 38, 1029-1037.

13. Swietlinska Z, Žuk J (1978):Cytotoxic effects of maleic hydrazide. Mut Res, 55, 15-30.

14. Tagawa H, Tobita T, Matsuzaki TA (1995): Novel metabolite of maleic hydrazide in the tobacco plant. Biosci, Biotechnol Biochem, 59, 1753.

15. UNEP/FAO/PIC/IN (1999): Maleic hydrazide. CASNo: 123-33-1.

Erişim:[http://www.pic.int/incs/ICRC1/4)/English/icrc14.pdf]. Erişim Tarihi: 27.07.2004.

16. US Environmental Protection Agency (US EPA) (1998): Target organs and critical effects for compounds with reference dose values.

Erişim: [http://www.epa.gov/earth1r6/6pd/rcra c/pd-o/ appda4.pdf4-5]. Erişim tarihi:14.11.2004.

17. Van Der Heijden CA, Den Tonkelaar EM, GarbisBerkvens JM, Van Esch GJ (1981): Maleic hydrazide carcinogenicity study in rats. Toxicology, 19, 139-150.

18. Visscher SN (1983): Effects of abscisic acid in animal growth and reproduction. 553-579. In: Abscisic Acid. Addicott FT (Eds), Praeger Science, New York.

19. World Health Organization (WHO) (2002): Pesticide Residues in Food. Toxicological Evaluations. Ethephon. 77-83. JMPR (WHO/PCS/03.1). World Health Organization Geneva, 2003.

Geliş tarihi: 07.06.2007 / Kabul tarihi: 05.07.2007
Address for correspondance
Selma Yazar, DVM Ph.D.
Ankara University Faculty of Veterinary Medicine
Dept. of Pharmacology and Toxicology
06110, Ankara, Turkey
e-mail:yazar@veterinary.ankara.edu.tr 